\title{
Behavioral Aspects: Search Engine optimization Strategy focusing for new entrants
}

\author{
S.Nandhini ${ }^{1}$, Ananth Selvakumar ${ }^{2}$, Dr. K. Santhana Lakshmi ${ }^{3}$, Dr.Martin Selvkumar ${ }^{4}$ \\ 1 nandyswamy1987@gmail.com \\ 2 as0718@srmist.edu.in \\ ${ }^{3}$ College of Management, SRM Institute of Science\& Technology, Kattankulathur, Chengalpattu Dt., Tamilnadu- \\ 603203, India santhank@ srmist.edu.in \\ ${ }^{4}$ Great Lakes Institute of Management, Tirukazhukundram, Chengalpattu Dt., Tamilnadu-603203, India \\ martinselvakumar.m@greatlakes.edu.in
}

Article History: Received: 10 January 2021; Revised: 12 February 2021; Accepted: 27 March 2021; Published online: 10 May 2021

\begin{abstract}
The main objective of this research is to identify the problems faced in marketing and sales of industrial flooring products in specialty flooring chemicals industries. The major problems that was noticed here was that industries that use flooring stick to existing supplier or purchasing from supplier who are already in market. Understanding this problem for new entrants, a strategy was developed for marketing to overcome the obstacle faced by new industrial flooring companies. To indentify further details on this, a survey was conducted mostly among industries and few restaurants to come to a conclusion on the decision factor for strategy and analysed responses highlighted the reason for not using and also why do they stick to existing supplier if they are using industrial flooring. The suggestion that has been made in this report is use of an effective search engine optimization strategy (SEO) will increase the web traffic to $50 \%$ of those who use the internet these days for such purpose. Once this done next is to implement social sales that is educate, social network and engage which can be used to make them aware about the necessity of industrial flooring which increases sales by almost $40 \%$. All these plans may be different in names by they come under the concept of Account Based Marketing (ABMs) which is developing and effective marketing strategy that has constructive impact on company's revenue.
\end{abstract}

\section{Introduction}

Industrial flooring is playing a very vital role in current generation in field of production, safety as well as housekeeping. There exists various range of floor covering systems suitable for various applications. Shifting trend towards protection to floors in transportation, chemical, manufacturing as well as food processing industries has created a rise the coating industrial floors demand. Increasing infrastructure spending by companies in manufacturing sector has become the key variable that stimulates industrial flooring's market growth. From this it is clear that the rise in manufacturing sector is directly influencing the implementation of floor coating in these facilities.

\begin{tabular}{|c|c|c|}
\hline \multicolumn{2}{|c|}{ Table 1: Industrial Floor Coatings Market Report Coverage } \\
\hline $\begin{array}{c}\text { Report } \\
\text { Coverage }\end{array}$ & Details \\
\hline Base Year: & 2017 & Market Size in 2017: 4.1 Billion (USD) \\
\hline
\end{tabular}




\begin{tabular}{|c|c|c|}
\hline Historical Data & 2013 to 2017 & Forecast Period: 2018 to 2024 \\
\hline $\begin{array}{c}\text { Forecast Period } \\
2018 \text { to } 2024 \\
\text { CAGR: }\end{array}$ & $7.2 \%$ & 2024 Value Projection: 7 Billion (USD) \\
\hline Growth Drivers: & \multicolumn{2}{|c|}{$\begin{array}{l}\text { - Growing construction spending on manufacturing sectors along } \\
\text { with the rise in count of small-scale industries } \\
\text { - } \quad \text { Increasing inflows of FDI } \\
\text { - Strong point of view in industries like food processing as well as } \\
\text { manufacturing along with technological advancements }\end{array}$} \\
\hline $\begin{array}{c}\text { Pitfalls \& } \\
\text { Challenges: }\end{array}$ & \multicolumn{2}{|c|}{$\begin{array}{l}\text { - Irregular raw material value } \\
\text { - } \quad \text { Partial operational limitation \& high product prices }\end{array}$} \\
\hline
\end{tabular}

The above table gives a clear view on strong dominance by $50 \%$ market demand and is expected to witness more than 6\% CAGR till 2024. This is due to the evident boost in industry shares due to the surge that exist in the adoption of industrial flooring to maintain a smooth finish with non-porous and low maintenance properties. It is observed that there will be about $8 \%$ revenue growth by 2024 in the market of industrial floor coating in Asia Pacific alone owing to a strong presence of manufacturing industries in this region. The background of industrial floor coating industry is that the finishing technology is the fastest growing market segment due to the enhanced components use for multiple applications in various industries. This industrial floor coating is preferred in solution to ground surface owing to long durability and a property of adhesiveness which has increased its demand in market. There is an increased demand noticed for industrial floor coating in categories such as automotive, food and beverage and also chemical sectors.

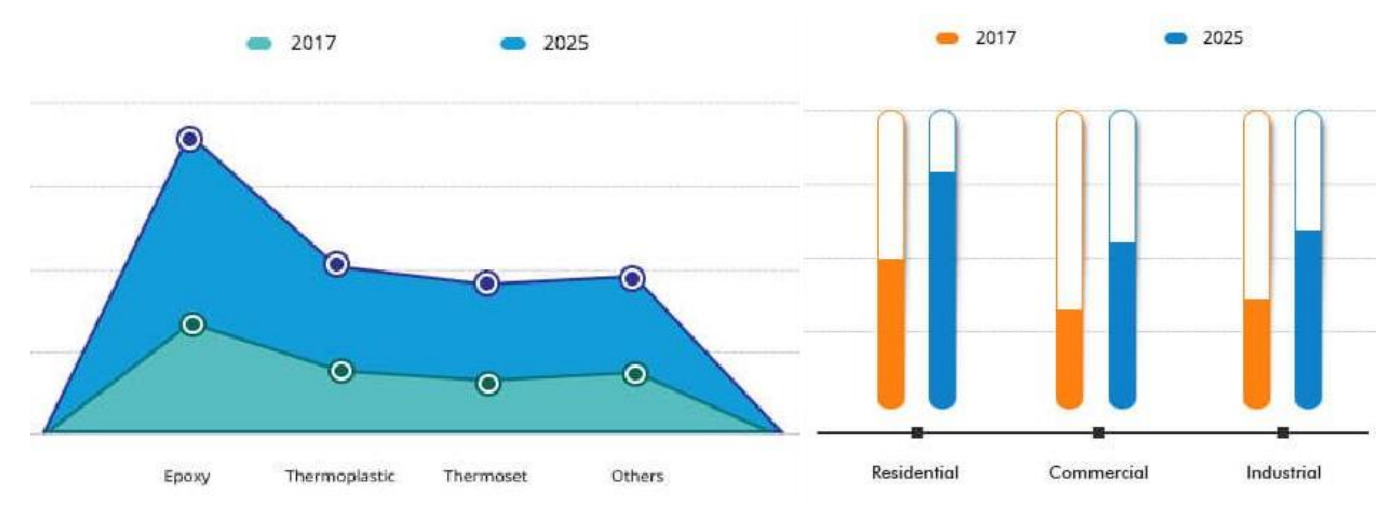

Fig 1:- Indian Floor Coating Market(left)\&Indian Floor Coatings Market (right)

When it comes to industrial flooring in Indian region, the market accounted 56,000 dollar in 2017 and it is forecasted to reach at least 90,000 dollar by 2025 by registering a CAGR of 6\% in 2025 from 2018. Commercial growth activities in India such as restaurants as well as new hotel construction have a significant opportunity for rise of Indian floor coating market. The market of floor coating in India is majorly driven by increased demand from end users in commercial, industrial and residential categories.End user basis, the residential segment dominated the market in 2017 as per sales and also dominated the market in 2025 based on the estimation. This in turn has increased the adoption of floor coatings for residential construction.

\section{Literature Review}

[1] A report on the title "Industrial Flooring by Tremix Vacuum System" by Hebin J. This report clearly explains about the industrial flooring done by tremix vacuum system. Their study was on the project that was carried out to remove the excess amount of water from the newly leveled concrete surfaces. Their 
analysis shows that this method of vacuum treatment will always improve impact and abrasion resistance of concrete surface. This concept basically acts as a replacement for industrial flooring in current market but it must be done often to maintain the floor while flooring needs to be done only every 3 to 5 years.

[2] "Causes of failures of industrial floors and concrete surfaces" a report by Kiernozycki is an article on the cases which lead to damage to industrial floor and road concrete. These damages can be avoided mostly by coating the floors using certain chemicals designed for industrial flooring. The damage is caused either due to excess load or due to wrong design and execution of force loads. In this article he analyzed the reason for damage occurrence and also recommendations given to repair in which one was to protect floor using industrial flooring.

[3] A report entitled "Industrial Flooring: A Revolution in Concrete Floors-Free Movement and Its Importance" by Manoj Didwania talks about the growth of industrial flooring in time. In time most of the industries have started to give importance to floor maintenance and protection due to constant increase in load that is being held by the floor.

[4] The concept of market share and forecast on industry by Aniket Sharma on the title "Construction Chemicals Market Share \& Industry Forecast". This article is an depth analysis of the market that is covering the size, growth, value as well as current trend for the period of 2018-2025 based on previous (historical) data. This paper proves a $6.0 \%$ growth in the sales of all industrial flooring products in the market in next 5 years. Moreover this article covers wide spectrum of services related to industrial flooring such as market opportunity analysis, latest technology as well as the competitive landscape in the market too.

\section{Research Methodology}

As mentioned in abstract the main objective of this research is focused on creating a marketing and sales strategy to increase the sales in near future for any speciality flooring chemical manufacturing industry in market by understanding customer needs and analyzing it along with reference to past data's. Most of the industries currently use only door to door sales strategy which is commonly being followed by all the industries. The secondary data obtained from one of the certified website is that in next 10 years the CAGR for industrial flooring market will increase at rate of $4.2 \%$ as shown in the below image (source: persistence market research, 2019). The method that was used here to understand the customer behaviour and their expectations is survey through a questionnaire. There are various methods to understand such as interview, survey, and sampling but for this case survey is best suitable one. The target respondent for this survey is manufacturing industries, shopping malls as well as restaurants where heat, load are involved.

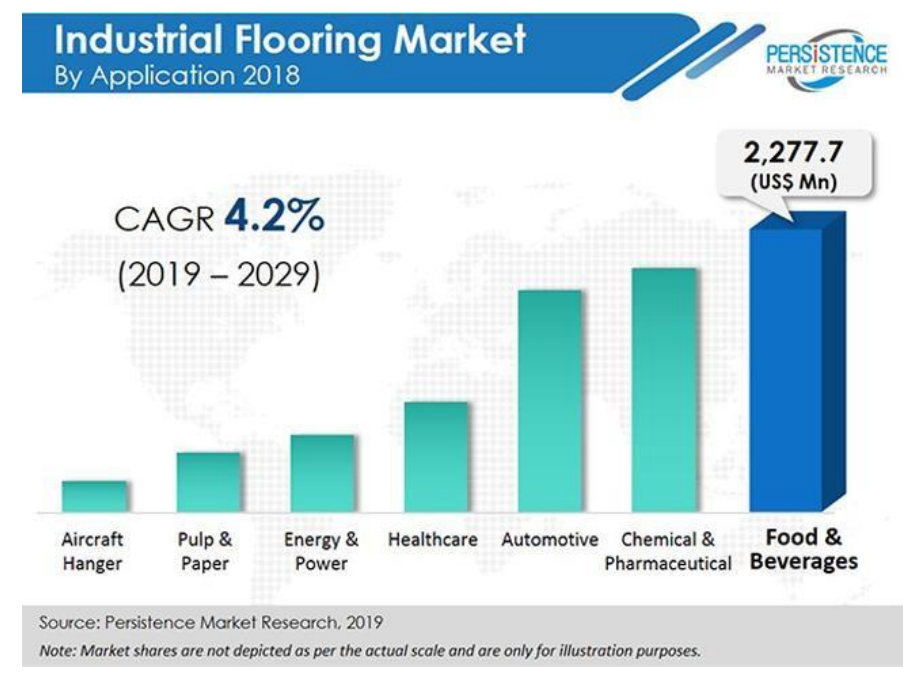


Fig 2: Industrial Flooring Market

\section{Research Questions}

To understand the customer behaviour and needs a survey with 16 questions was prepared after understanding the company, product, market as well as target customer. The questions as well the reason for its existence in the survey i.e. what can be expected from answer of that particular question in survey is given below table.

\begin{tabular}{|c|c|c|}
\hline Question & Type of Question & Why \\
\hline Which company you belong to? & Fill in the Blanks & \multirow[b]{3}{*}{$\begin{array}{l}\text { These set of question is to } \\
\text { understand where are they } \\
\text { from and what product / } \\
\text { service are they currently } \\
\text { using in shop floor }\end{array}$} \\
\hline Your mail ID please! & Fill in the Blanks & \\
\hline $\begin{array}{c}\text { Out of these which all processes } \\
\text { have you already implied in } \\
\text { your industry? }\end{array}$ & $\begin{array}{l}\text { Multiple Choice Question } \\
\text { a) Industrial flooring } \\
\text { b) Concrete repair and rehabilitatior } \\
\text { c) Industrial and injection grouting } \\
\text { d) Waterproofing and sealing } \\
\text { e) Fire-stops and fire sealants }\end{array}$ & \\
\hline $\begin{array}{c}\text { How long have you been using } \\
\text { the above selected products / } \\
\text { services and how many years } \\
\text { once you re use it? }\end{array}$ & Fill in the Blanks & $\begin{array}{l}\text { we can know how often they } \\
\text { purchase our product / service }\end{array}$ \\
\hline $\begin{array}{l}\text { How long have you been using } \\
\text { the above selected products / } \\
\text { services and how many years } \\
\text { once you re use it? }\end{array}$ & Fill in the Blanks & $\begin{array}{l}\text { we can know how often they } \\
\text { purchase our product / service }\end{array}$ \\
\hline Question & Type of Question & Why \\
\hline $\begin{array}{l}\text { Most of industries haven't done } \\
\text { industrial flooring in their shop } \\
\text { floor. Why? }\end{array}$ & $\begin{array}{l}\text { Multiple Choice Question } \\
\text { a) Not aware } \\
\text { b) Not interested } \\
\text { c)Don't think highly necessary } \\
\text { Others }\end{array}$ & \multirow{3}{*}{$\begin{array}{l}\text { These questions understand their } \\
\text { possible reason for not using, their } \\
\text { satisfaction rate and mode of } \\
\text { purchase }\end{array}$} \\
\hline $\begin{array}{l}\text { With reference to industrial } \\
\text { flooring what are the brands / } \\
\text { products you have tried out and } \\
\text { what made you select it? }\end{array}$ & Fill in the Blanks & \\
\hline $\begin{array}{l}\text { Have you ever checked the } \\
\text { product \& service with other } \\
\text { suppliers? How much are you } \\
\text { satisfied with the current } \\
\text { product / service's } \\
\text { performance? }\end{array}$ & $\begin{array}{l}\text { Yes / No question } \\
\& \text { Ranking } 1 \text { to } 5\end{array}$ & \\
\hline $\begin{array}{l}\text { With reference to industrial } \\
\text { flooring what are the brands / } \\
\text { products you have tried out and } \\
\text { what made you select it? }\end{array}$ & Fill in the Blanks & \multirow{2}{*}{$\begin{array}{l}\text { Factors for selection, what } \\
\text { suppliers provide and their } \\
\text { expectation }\end{array}$} \\
\hline $\begin{array}{l}\text { Have you ever checked the } \\
\text { product \& service with other }\end{array}$ & $\begin{array}{c}\text { Yes / No question } \\
\&\end{array}$ & \\
\hline
\end{tabular}




\begin{tabular}{|c|c|}
\hline $\begin{array}{c}\text { suppliers? How much are you } \\
\text { satisfied with the current } \\
\text { product / service's } \\
\text { performance? }\end{array}$ & Ranking 1 to 5 \\
\hline $\begin{array}{c}\text { Why do you stick to your } \\
\text { existing suppliers and purchase } \\
\text { from them only: } \\
\begin{array}{c}\text { Regular discount b) Promotion } \\
\text { c) Recognized brand d) Quality } \\
\text { e) Quantity f) Price }\end{array}\end{array}$ & Multiple Choice Question \\
\hline $\begin{array}{c}\text { What improvements do you } \\
\text { think industries (industrial } \\
\text { flooring) need to do in its } \\
\text { product and services for } \\
\text { increasing customer } \\
\text { satisfaction? }\end{array}$ & \\
\hline
\end{tabular}

\section{Interpretation}

Frequency Table:

Most industries haven't done industrial flooring in their shop. Why?

\begin{tabular}{|c|c|c|c|c|c|}
\hline & & Frequency & Percent & Valid Percent & $\begin{array}{c}\text { Cumulative } \\
\text { Percent }\end{array}$ \\
\hline \multirow[t]{6}{*}{ Valid } & $\begin{array}{c}\text { Don't think highly } \\
\text { necessary }\end{array}$ & 26 & 32.5 & 32.5 & 32.5 \\
\hline & $\begin{array}{c}\text { It's enough for this } \\
\text { applicant }\end{array}$ & 1 & 1.3 & 1.3 & 33.8 \\
\hline & No. It's must & 1 & 1.3 & 1.3 & 35.0 \\
\hline & Not aware & 50 & 62.5 & 62.5 & 97.5 \\
\hline & Not interested & 2 & 2.5 & 2.5 & 100.0 \\
\hline & Total & 80 & 100.0 & 100.0 & \\
\hline
\end{tabular}

Have you ever checked the product / service with other suppliers?

\begin{tabular}{|lc|c|c|c|c|}
\hline & & & & & Cumulative \\
& & Frequency & Percent & Valid Percent & Percent \\
\hline Valid & & 1 & 1.3 & 1.3 & 1.3 \\
& No & 5 & 6.3 & 6.3 & 7.5 \\
& Yes & 74 & 92.5 & 92.5 & 100.0 \\
& Total & 80 & 100.0 & 100.0 & \\
\hline
\end{tabular}


How much are you satisfied with the current product / service?

\begin{tabular}{|cc|c|c|c|c|}
\hline & & Frequency & Percent & Valid Percent & $\begin{array}{c}\text { Cumulative } \\
\text { Percent }\end{array}$ \\
\hline Valid & 2 & 2 & 2.5 & 2.6 & 2.6 \\
& 3 & 39 & 48.8 & 50.0 & 52.6 \\
4 & 33 & 41.3 & 42.3 & 94.9 \\
& 5 & 4 & 5.0 & 5.1 & 100.0 \\
& Total & 78 & 97.5 & 100.0 & \\
Missing System & 2 & 2.5 & & \\
\multicolumn{1}{|c|}{ Total } & 80 & 100.0 & & \\
\hline \multicolumn{4}{|r|}{}
\end{tabular}

Will you deal with the industrial flooring service through consultancy / directly with organization?

\begin{tabular}{|c|c|c|c|c|c|}
\hline & & Frequency & Percent & Valid Percent & $\begin{array}{c}\text { Cumulative } \\
\text { Percent }\end{array}$ \\
\hline Valid & & 2 & 2.5 & 2.5 & 2.5 \\
\hline & Affliators & 11 & 13.8 & 13.8 & 16.3 \\
\hline & Consultancy / Affiliation & 3 & 3.8 & 3.8 & 20.0 \\
\hline & Directly with the & 64 & 80.0 & 80.0 & 100.0 \\
\hline & Total & 80 & 100.0 & 100.0 & \\
\hline
\end{tabular}

What are all the factors impacts you to choose the supplier?

\begin{tabular}{|c|c|c|c|c|c|}
\hline \multicolumn{2}{|c|}{} & Frequency & Percent & Valid Percent & $\begin{array}{c}\text { Cumulative } \\
\text { Percent }\end{array}$ \\
\hline Valid & 2 & 2.5 & 2.5 & 2.5 \\
\cline { 2 - 6 } & Appearance.;Maintenance & 5 & 6.3 & 6.3 & 10.0 \\
\cline { 2 - 6 } & Initial Cost & 4 & 5.0 & 5.0 & 18.8 \\
\cline { 2 - 6 } & $\begin{array}{c}\text { Initial } \\
\text { Cost;Appearance.;Durabil } \\
\text { ity;Maintenance }\end{array}$ & 5 & 6.3 & 6.3 & 30.0 \\
\cline { 2 - 6 } & Initial Cost;Durability & $\mathbf{1 3}$ & $\mathbf{1 6 . 3}$ & $\mathbf{1 6 . 3}$ & $\mathbf{5 5 . 0}$ \\
\cline { 2 - 6 } & $\begin{array}{c}\text { Initial } \\
\text { Cost;Durability;Mainte } \\
\text { nance }\end{array}$ & $\mathbf{1 6}$ & $\mathbf{2 0 . 0}$ & $\mathbf{2 0 . 0}$ & $\mathbf{7 5 . 0}$ \\
\cline { 2 - 6 } & $\begin{array}{c}\text { Initial } \\
\text { Cost;Maintenance }\end{array}$ & $\mathbf{1 1}$ & $\mathbf{1 3 . 8}$ & $\mathbf{1 3 . 8}$ & $\mathbf{9 1 . 3}$ \\
\hline
\end{tabular}


Why do you stick to your existing suppliers and purchase from them only?

\begin{tabular}{|c|c|c|c|c|}
\hline \multicolumn{2}{|c|}{} & Frequency & Percent & Valid Percent \\
\hline Valid & & 2 & 2.5 & 2.5 \\
\cline { 2 - 5 } & Quality & 3 & 3.8 & 3.8 \\
\cline { 2 - 5 } & Quality;Price & 3 & 3.8 & 3.8 \\
\cline { 2 - 5 } & Recognized brand & $\mathbf{1}$ & $\mathbf{3 3 . 1 3}$ & $\mathbf{3 3 . 1 3}$ \\
\cline { 2 - 5 } & Regular discount; Quality & $\mathbf{1 9}$ & $\mathbf{2 3 . 8}$ & $\mathbf{2 3 . 8}$ \\
\cline { 2 - 5 } & Regular discount; Quantity & $\mathbf{1 0}$ & $\mathbf{1 2 . 5}$ & $\mathbf{1 2 . 5}$ \\
\hline
\end{tabular}

What improvements do you think industries need to do in their product / service?

\begin{tabular}{|c|c|c|c|c|c|}
\hline \multicolumn{2}{|c|}{} & Frequency & Percent & Valid Percent & $\begin{array}{c}\text { Cumulative } \\
\text { Percent }\end{array}$ \\
\hline \multirow{3}{*}{ Valid } & & 2 & 2.5 & 2.5 & 2.5 \\
\cline { 2 - 6 } & Durability & 14 & 17.5 & 17.5 & 25.0 \\
\cline { 2 - 6 } & Maintenance & 7 & 8.8 & 8.8 & 37.5 \\
\cline { 2 - 6 } & quality & 8 & 10.0 & 10.0 & 70.0 \\
\cline { 2 - 6 } & Supply time & 6 & 7.5 & 7.5 & 83.8 \\
\cline { 2 - 6 } & Sustainability & 6 & 7.5 & 7.5 & 96.3 \\
\hline
\end{tabular}

Are you ready to accept a new supplier who provides a better product / service?

\begin{tabular}{|lc|c|c|c|c|}
\hline & & & & & Cumulative \\
& & Frequency & Percent & Valid Percent & Percent \\
\hline Valid & & 2 & 2.5 & 2.5 & 2.5 \\
& No & 4 & 5.0 & 5.0 & 7.5 \\
& Yes & 74 & 92.5 & 92.5 & 100.0 \\
& Total & 80 & 100.0 & 100.0 & \\
\hline
\end{tabular}

\section{Chi-Square Test}

The Chi-square test is intended to test how likely it is that an observed distribution is due to chance. It is also called a "goodness of fit" statistic, because it measures how well the observed distribution of data fits with the distribution that is expected if the variables are independent.

\section{Frequencies}


How much are you satisfied with the current product / services?

\begin{tabular}{|c|c|c|c|}
\hline & Observed N & Expected N & Residual \\
\hline 2 & 2 & 19.5 & -17.5 \\
\hline 3 & 39 & 19.5 & 19.5 \\
\hline 4 & 33 & 19.5 & 13.5 \\
\hline 5 & 4 & 19.5 & -15.5 \\
\hline Total & 78 & & \\
\hline
\end{tabular}

Test Statistics

\begin{tabular}{|c|c|}
\hline & $\begin{array}{c}\text { How much are you satisfied with the current product } \\
/ \text { services? }\end{array}$ \\
\hline Chi-Square & $56.872^{\mathrm{a}}$ \\
\hline $\mathrm{df}$ & 3 \\
\hline Asymp. Sig. & .000 \\
\hline $\begin{array}{l}\text { a. 0 cells (.0\%) have expected frequencies less than 5. The } \\
\text { minimum expected cell frequency is } 19.5 \text {. }\end{array}$ \\
\hline
\end{tabular}

From the above analysis (test statistics) using SPSS (Chi Square Test) it is clear that the cells have the expected frequency of less than 5 . And also it can be clearly observed that the expected minimum frequency is obtained in the $2^{\text {nd }}$ row i.e. 3 rating on satisfaction by customer on currently used products and its brand.And one rating that is closest to the expected frequency (19.5) is rating 4 that have a frequency of 13.5. The p-value is significant at $1 \%$ and $5 \%$. So there is an association in the comparison performed here. The $\mathrm{df}$ is rating 3 and the $\mathrm{p}$-value is calculated to be .000 .

\section{Graph}

The major decision making questions response has been compared through graph plots which supported in coming to a result on what to be focused majorly while promotion and sales of industrial flooring is done. To get this comparison graph also SPSS software was used and linear graph and area diagram were used to compare the questions as shown below. 


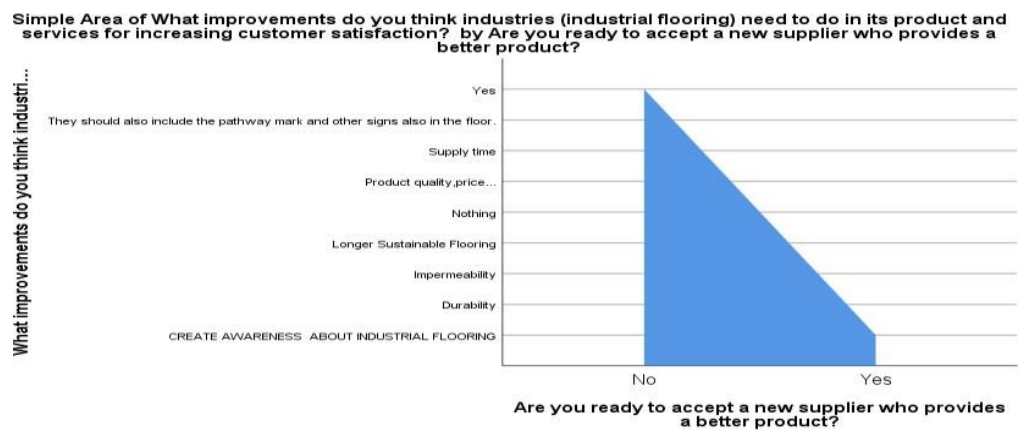

Fig 3: Graph - 1

The interpretation of second graph obtained is as shown in the below image. Just like the previous graph interpretation $t$ he high frequency answer for both the question is indentified from the frequency test table above. Then those answers are used as a factor of comparison in the graph on $\mathrm{x}$ and $\mathrm{y}$ axis to come to the conclusion in the middle of the below figure. According to comparison it was clear the customers focus majorly on the products durability. So if the seller focuses on also creating awareness about industrial flooring they will have a better chance in sales as well as sustaining the existing customer in near future too.

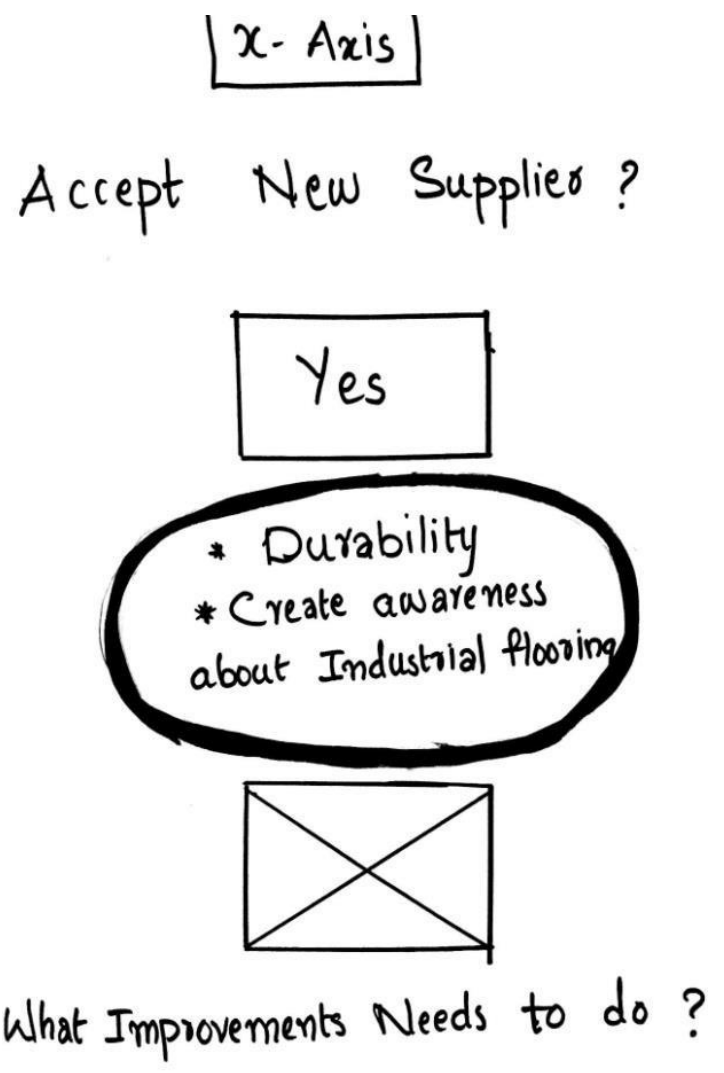

Yy. Axis

Fig 4: Graph 4 Interpretation

\section{Suggestion \& Recommendation}


The analysis very much clearly states that most of the industries either are not aware or only approach brand and avoid new entrants. The concept of door to door sales is profitable to the organization only when the above factors of not being aware and promoting new entrants thoughts are nullified. To accomplish this objective obtained from the analysis the strategy that is suggested in this project is "“ABMs" and "Search Engine Optimization".

$A B M s$

ABMs stands for account based marketing, the concept of marketing about the product and service through accounts in various channels such as social media etc. The helps in creating a direct communication with the decision maker in any company which can a CEO, BODs, MD, purchase head etc. This is generally done by externally agency who have control over most of the target market with their details who provide for a payment of fee for data or even to act as external marketing agency for the company.

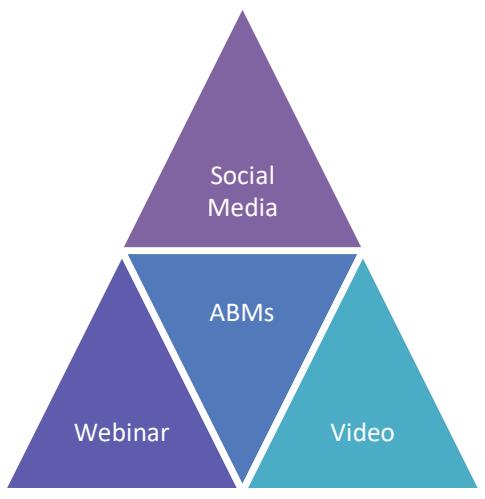

Fig 5: ABMs Concept

\section{Search Engine Optimization}

SEO also known as search engine optimization is the concept of improving the website ranking through a payment done any search engine. This makes sure when certain keywords are used the company website and details will be suggested in top results so as to increase the traffic for the company's website inside which videos, pamphlets and designs can be used to attract and convince customer to purchase the product. It does not only help in optimizing the search result but at same time it provides real time reporting, improved rank and more than 50\% of people who search for industrial flooring will be suggested about the brand and its product with features which improves the sales return for the company. From below image it is clear that people who go beyond page 1 is $49 \%$ while beyond page 2 is just $15 \%$. So as to make it clear without search engine optimization the company's brand and product cannot be brought forth to most of target customers and this clearly states the necessity for the existence of SEO as an concept to be used in this case we are seeing. 

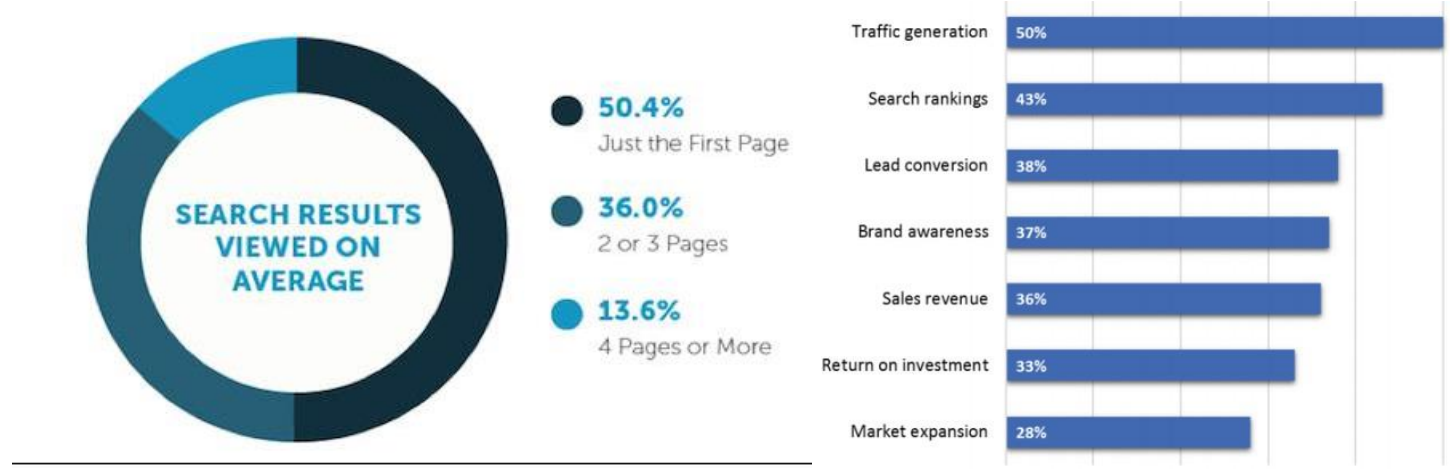

Fig 6: SEO\&SEO Result

\section{Conclusion}

The results highlighted the reason for not using and also why do they stick to existing supplier if they are using industrial flooring. The suggestion that has been made in this report is use of an effective search engine optimization strategy (SEO) will increase the web traffic to 50\% of those who use the internet these days for such purpose. Once this done next is, according to B2B marketing platform LinkedIn and twitter (social media) has greater impact on sales rise in any product or service which is an added advantage to the company's brand and product marketing at low cost. All these plans may be different in names by they come under the concept of Account Based Marketing (ABMs) which is developing and effective marketing strategy that has constructive impact on company's revenue.

\section{Reference}

[1] Hebin J, "Industrial Flooring by Tremix Vacuum System" published 6 Apr, 2017.

[2] Kiernozycki W., "Causes of failures of industrial floors and concrete surfaces - case study" MATEC Web of Conferences 284(1):04002 January 2019.

[3] Manoj Didwania, "Industrial Flooring: A revolution in concrete floors free movement and its importance".

[4] Guidance on the design of a floor is in detailed specified in the UK concrete society's Technical Report 34 (TR34).

[5] Aniket Sharma, "Construction chemicals market share \& industry forecast research report, 2018-2025" February 2019 in researchgate.

[6] Horsfield M, Ansell P, "Aggregates for industrial flooring: An overview" in researchgate in august 2002

[7] Sudor, Marushchak, Braichenko, Margal, "Modified fiber reinforced concrete for industrial floors" in researchgate December 2019. 